\title{
EFFect of Weed Interference on Soybean Cultivars at Two SowING TIMEs ${ }^{1}$
}

\author{
Interferência de Plantas Daninhas com Cultivares de Soja em Duas Épocas de Semeadura
MARANGONI, R.E. ${ }^{2}$, JAKELAITIS, A. ${ }^{3}$, TAVARES, C.J. ${ }^{2}$, REZENDE, B.P.M. ${ }^{2}$, MELLO FILHO, O.L. ${ }^{4}$, and CUNHA, P.C.R. ${ }^{5}$

\begin{abstract}
This study aimed to evaluate the effects of weed interference on soybean cultivars at two sowing times in Urutaí, GO. The treatments were arranged in split-plots, and the sowing times (November 16 and December 16, 2009) were allocated in the plots; the soybean cultivars [BRSGO Amaralina, P98C81 (semi-late cycle) BRSGO Raissa, BRSGO Indiara, P98Y11 (median cycle) and BRSGO 7560, BRSGO Caiapônia, Emgopa 302RR (early cycle)] were allocated in the split-plots; and the coexistence or non coexistence of soybean cultivars with weeds, throughout their cycle, was allocated in the split-plots. Non coexistence was established by manual weeding. The experiment was arranged in randomized blocks with four replications. It was verified that the optimal time for sowing soybeans was the month of November, and that under these conditions, the cultivars had higher competitive ability against weeds. Late sowing affected the cycle, development, and yield of the soybean cultivars; this effect was greater under the influence of the weed community.
\end{abstract}

Keywords: Glycine max, competition, crop yield.

RESUMO - Objetivou-se avaliar os efeitos da interferência de plantas daninhas sobre cultivares de soja, em duas épocas de semeadura em Urutai, GO. Os tratamentos foram arranjados em parcelas subsubdivididas, sendo nas parcelas alocadas as épocas de semeadura (16 de novembro e 16 de dezembro de 2009); nas subparcelas, os cultivares de soja [BRSGO Amaralina, P98C81 (ciclo semitardio), BRSGO Indiara, BRSGO Raíssa, P98Y11 (ciclo médio) e BRSGO 7560, BRSGO Caiapônia, Emgopa 302RR (precoce)]; e nas subsubparcelas, a convivência ou não de os cultivares de soja com plantas daninhas, portodo o ciclo destas. A não convivência entre eles foi estabelecida por capinas manuais. O ensaio foi montado em blocos ao acaso com quatro repetições. Foi observado que a época indicada para semeadura dos cultivares de soja foi o mês de novembro e que, nessa condição, os cultivares apresentaram maior capacidade competitiva com as plantas daninhas. O atraso na semeadura dos cultivares de soja afetou o ciclo, o desenvolvimento e a produtividade da soja, sendo esse efeito maximizado quando houve a interferência da comunidade infestante.

Palavras-chave: Glycine max, competição, rendimento de grãos.

\section{INTRODUCTION}

Soybean is the most important oilseed crop grown worldwide. Brazil is the world's second largest producer and Latin America's largest producer, as well as a leading global exporter. In the 2011/2012 season, it was estimated that about 25 million acres of soybeans were cultivated in Brazil, producing around 66.4 million tons of seeds

1 Recebido para publicação em 2.6.2012 e aprovado em 5.11.2012.

2 Graduando em Engenharia Agronômica, Instituto Federal Goiano - IF Goiano, Campus Urutaí, 75790-000 Urutaí-GO, Bolsistas CNPq<rogerio_marangoni@hotmail.com>, <cassiojardimtavares@hotmail.com>, <bernardopiccolomoreira@hotmail.com>; ${ }^{3}$ Engo-Agro ${ }^{\circ}$, Professor IF Goiano, Campus Rio Verde, 75901-970 Rio Verde-GO, <ajakelaitis@yahoo.com.br>; ${ }^{4}$ Engo-Agr ${ }^{0}$, D.Sc. em Genética e Melhoramento, Pesquisador EMBRAPA - CNPSO, 74001-970 Goiânia-GO, <olemos@cnpso.embrapa.br>; ${ }^{5}$ Eng - -Agr ${ }^{0}$, Professor IF Goiano, Campus Urutaí, <pcdacunha@hotmail.com>. 
(CONAB, 2012). Soybean stands out as an extremely relevant crop in Brazil's economy because it is used as feedstock for a variety of industrial products, whose manufacture involves significant investment and large numbers of people. Soybean is primarily used for human consumption as beans, flour, textured protein, extracts and oils, and animal feed for poultry, swine and ruminants. It is also used in paints, lubricants, plastics and varnishes (Sediyama et al., 2009). Currently, soybeans have been extensively used to produce vegetable oil for biofuels, accounting for about $90 \%$ of the feedstock for biodiesel production in Brazil (Ferrari et al., 2005, Barbosa et al., 2011).

This crop has great adaptability to the weather in Brazil; however, it is subject to a number of factors that affect its development and production. The factors that act directly on the crop include photoperiod, solar radiation, temperature, rainfall, humidity and soil fertility (Barros \& Sedyiama 2009), which makes sowing time the main cultivation component that, alone, most affects the cycle and productivity of soybean (Mota et al., 2000; Barros et al., 2003). For this reason, it becomes imperative to evaluate the agronomic performance of soybean cultivars at different sowing times and in different regions in order to recommend the most favorable sowing time (Bonato et al., 1998). In Goiás, the fourth largest domestic soybean producer, the best results for most cultivars were obtained when sowing was carried out in the second half of October and in November (Silveira Neto et al., 2005; Embrapa, 2010).

Soybean plants have plasticity to adapt to various environmental conditions through changes in plant morphology, canopy architecture and yield components, and these changes are associated with soil fertility, plant density, sowing time and inter-row spacing (Rambo et al., 2003). Evaluating this plasticity is crucial because soybean has been shown to be sensitive to weed interference, which is of great importance during the development of the crop. Weeds not only compete for environmental resources and release allelopathic substances but also interfere in the process of harvesting and are host to many pest insects, nematodes and pathogens that cause various diseases. In certain regions, weed-induced soybean crop losses can reach $80 \%$ if not properly handled (Gazziero et al. 2004).

Soybean cultivars may change the composition of weed populations in agroecosystems, because some of them have high competitive ability against weeds (Pires et al., 2005). This was observed by Lamego et al. (2004), who showed that soybean cultivars with high competitive ability are tolerant to competition, thus preserving their productive potential as well as decreasing the production of competing plants. This is why it is important to perform weed management in agroecosystems by using cultivars with high competitive ability against weeds (Teixeira et al., 2009). This ability lies in the rate of initial growth and occupancy of ecological niches, which are directly associated with the quick and efficient use of resources, such as solar radiation, and the formation of vigorous root systems as well as the optimal use of water and nutrients by cultivars (Radosevitch et al., 1997, Pires et al., 2005).

Given that the relative performance of cultivars varies among cultivation environments, it is essential to evaluate different materials in several locations, years, sowing times and levels of technology in order to verify the productive potential of such cultivars and also check their competition against weeds. In short, the objective of this study was to evaluate the competitive interactions between weeds and soybean cultivars established at two sowing times in Urutai-GO in the agricultural year 2009/2010.

\section{MATERIAL AND METHODS}

The study was conducted in the municipality of Urutai, GO, under coordinates $17^{\circ} 28^{\prime} 41^{\prime \prime} \mathrm{S}$ and $48^{\circ} 11^{\prime} 35^{\prime \prime} \mathrm{E}$ and $800 \mathrm{~m}$ of altitude, under field conditions during the months of $10 / 2009$ to $05 / 2010$. The soil in the experimental area is a dystrophic Oxisol, containing particles of 35,10 and $55 \%$ clay, silt and sand, respectively. Before the test was performed, soil was collected at 0 to $20 \mathrm{~cm}$ for chemical analysis, whose characteristics were: $\mathrm{pH}$ in water of $5.7, \mathrm{~K}, \mathrm{Ca}, \mathrm{Mg}$ and $\mathrm{Al}+\mathrm{H}$ of $0,30,2.7,0.4$ and $2.6 \mathrm{cmol}_{\mathrm{c}} \mathrm{cm}^{-3}$, 
respectively, $\mathrm{P}$ of $53 \mathrm{mg} \mathrm{dm}^{-3}$; organic matter of $1.2 \mathrm{~kg}$ dag kg-1, and $\mathrm{S}, \mathrm{Zn}, \mathrm{B}, \mathrm{Cu}, \mathrm{Fe}, \mathrm{Mn}$ and Mo of $5.6,5.6,0.12,1.8,47.3,27.0$, and $0.07 \mathrm{mg} \mathrm{dm}^{-3}$, respectively.

A chemical desiccation was performed of plants present in the experimental area with the herbicide glyphosate at $1,500 \mathrm{~g}$ a.e. $\mathrm{ha}^{-1}$; thirty days later, conventional tillage was performed with subsoiling, plowing and diskharrowing.

The experiment was conducted in a randomized complete block design with four replications, arranged in a $2 \times 8 \times 2$ split-plot design. The first factor consisted of two periods of soybean sowing, on November 16 and December 16, 2009, while the second factor consisted of eight soybean cultivars [BRSGO Amaralina, P98C81 (medium-late cycle), BRSGO Indiara, BRSGO Raíssa, P98Y 11 (medium cycle) and BRSGO 7560, BRSGO Caiapônia, Emgopa 302RR (early cycle)]; the third factor consisted of two weed management systems: the area of weeded plots without weed infestation throughout the cycle of cultivars, and the unweeded area, with the plots infested with weeds until harvest. Hand weeding was performed weekly until cultivation was completely finished. The experimental units consisted of eight four-meter long soybean rows, spaced at $45 \mathrm{~cm}$. The four central rows were considered as useful area for sampling and evaluation, with $50 \mathrm{~cm}$ being discarded at each end.

Before sowing, the soybean seeds were inoculated with a liquid inoculum containing $1 \times 10^{9}$ viable cells of the bacterium Bradyrhizobium japonicum (strain SEMIA 5080) per $\mathrm{ml}$ of product at a dosage of $100 \mathrm{~mL}$ for $50 \mathrm{~kg}$ of seeds. Fungicides carbendazim + thiram were also used at doses of $30+$ 70 grams of the active ingredient, respectively, for $100 \mathrm{~kg}$ of seeds. Sowing was manual, using 18 seeds per meter, deposited to a depth of $4 \mathrm{~cm}$. Sowing fertilization used $300 \mathrm{~kg} \mathrm{ha}^{-1}$ of fertilizer formulated 4-30-16 $\left(\mathrm{N}, \mathrm{P}_{2} \mathrm{O}_{5}, \mathrm{~K}_{2} \mathrm{O}\right)$. As phytosanitary treatments, fungicides epoxiconazole + pyraclostrobin were applied at doses of $25 \mathrm{~g}+66.5 \mathrm{~g} \mathrm{ha}^{-1}$ at 27 and 45 days after soybean emergence (DAE). At $27 \mathrm{DAE}$, foliar fertilizer Torped $\mathbb{R}$ was applied at a dose of $1 \mathrm{~L} \mathrm{ha}^{-1}$.
For characterization of the weed community in treatments where the culture coexisted with weeds, assessments were made at $26 \mathrm{DAE}$ and at harvest of soybean cultivars. For such purpose, two $0.25 \mathrm{~m}^{2}$ square samples were randomly taken from each experimental unit and the aerial parts of the weeds were collected soon after that; they were separated by species and their dry weight was determined. The dry weight of the weeds was obtained by drying them in a forced air ventilation system at $70{ }^{\circ} \mathrm{C}$ for 72 hours until constant weight.

At soybean harvest, crop yield was evaluated in the useful area of each experimental unit, and ten plants were chosen as representing the plants in the useful area. The total number of pods per plant was then determined. 200 pods were also randomly selected from such plants, and the number of seeds per pod and 100 seed weight were determined, in duplicate. The values of crop yield and 100 seed weight were expressed at $13 \%$ moisture. In addition, monitoring was performed of the number of days to flowering and maturity of cultivars, counted from emergence, required for one open flower, R1 stage, and $95 \%$ of mature pods, R8 stage, respectively (Fehr \& Caviness, 1977) on 50\% of the plants in each experimental unit.

The results for the weeds and yield components of soybeans were subjected to analysis of variance by the F-test $(p<0.05)$. The means of the significant variables were compared by the Tukey's test $(\mathrm{p}<0.05)$. The variables that did not meet the assumptions of the analysis of variance were turned into $\sqrt{ } x$ for analysis. The days to flowering and maturity of cultivars were subjected to descriptive analysis, which expressed the mean values. The data relating to rainfall and average temperature during the conduct of the study are shown in Figure 1.

\section{RESULTS AND DISCUSSION}

In general, variation was observed in the number of days to flowering and maturity of soybean cultivars (Table 1), converging to a reduced cycle when the cultivars were sown in December, compared to sowing in November. According to Urben Filho \& Souza (1993) and 


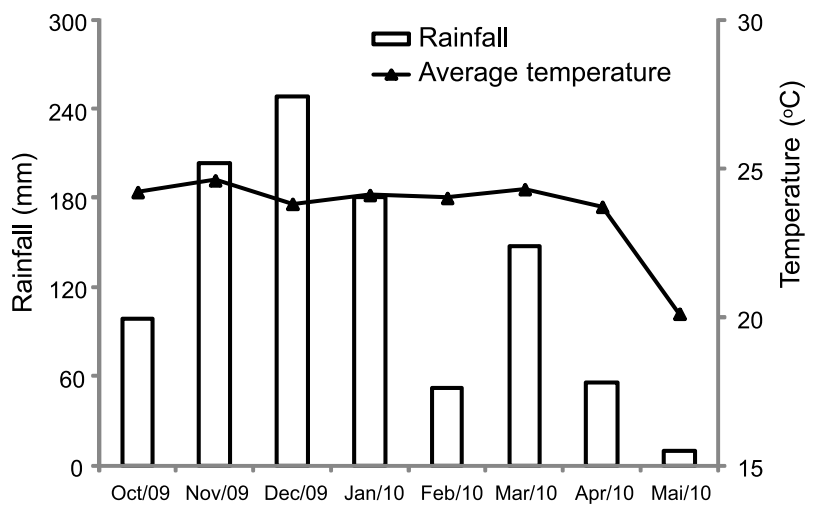

Figure 1 - Rainfall and average temperature during the conduct of research.

Table 1 - Number of days to flowering and maturity of soybean cultivars established at two sowing times

\begin{tabular}{|l|c|c|c|c|}
\hline \multirow{2}{*}{ Cultivars } & \multicolumn{2}{c|}{ 16 November } & \multicolumn{2}{c|}{ 16 December } \\
\cline { 2 - 5 } & Flowering & Maturity & Flowering & Maturity \\
\hline BRSGO Amaralina & 68 & 136 & 58 & 126 \\
\hline BRSGO 7560 & 48 & 111 & 45 & 101 \\
\hline BRSGO Raíssa & 55 & 120 & 52 & 112 \\
\hline BRSGO Caiapônia & 48 & 111 & 45 & 101 \\
\hline Emgopa 302 RR & 48 & 111 & 45 & 101 \\
\hline BRSGO Indiara & 55 & 120 & 52 & 112 \\
\hline P98C81 & 68 & 136 & 58 & 126 \\
\hline P98Y11 & 58 & 111 & 52 & 112 \\
\hline
\end{tabular}

Barros et al. (2003), studies conducted in the Brazilian savannah region show that changes in cycles of soybean cultivars are generally small compared with the variations perceived by cultivars when they are grown in southern Brazil. Soybean sowing held in November, assured by more favorable environmental conditions, possibly favored a better development of the cultivars; however, they were probably also affected by a drought in the most critical phase of their development (seed filling), which occurred in February (Figure 1). As expected, there was a tendency for reduction in the cycle of cultivars sown at a later time, shortening the vegetative and reproductive stages. Lower photoperiods during the late cultivation, and drought stress, especially when coupled with high temperatures, are factors that may contribute to a reduction in the cycle under late soybean cultivation as well as a reduction in the photoperiod. Peluzio et al. (2005) and Barbosa et al. (2011) observed a reduction in the cycle of soybean cultivars sown at a later time, given the shortening of the vegetative phase.

The summary of the analysis of variance is shown in Table 2 for all properties assessed in the weeds and soybeans. Concerning the weed community assessed at $26 \mathrm{DAE}$ and at harvest of soybean cultivars, the main weed species present in the evaluations were: Alternanthera tenella (joyweed), Portulaca oleracea (verdolaga), Galinsoga parviflora (gallant soldier), Brachiaria decumbens (signal grass), Digitaria horizontalis (Jamaican cabgrass), Acanthospermum hispidum (Bristly starbur), Sorghum arundinaceum (common wild sorghum), Eleusine indica (Indian goosegrass), Ipomoea triloba (littlebell), Amaranthus retroflexus

Table 2 - Mean square of treatments related to the variables evaluated in the weeds and soybeans, as regards sowing times (ST), soybean (SB), weed management (WM) and their interactions

\begin{tabular}{|c|c|c|c|c|c|c|c|c|}
\hline & \multirow{2}{*}{ Variable s } & \multicolumn{7}{|c|}{ Source of variability } \\
\hline & & ST & SB & WM & ST x SB & SB $\times$ WM & ST $\times$ WM & ST x SB x WM \\
\hline \multirow{6}{*}{$\begin{array}{l}\text { Dry weight } \\
\text { of weeds }\end{array}$} & Dicotyledons at $26 \mathrm{DAE}$ & $62.64^{\mathrm{ns}}$ & $18.87^{\text {ns }}$ & - & $11.76^{\text {ns }}$ & - & - & - \\
\hline & Dicotyledons at harvest & $3304.09^{*}$ & $160.72^{\text {ns }}$ & - & $155.86^{\mathrm{ns}}$ & - & - & - \\
\hline & Monocotyledons at 26 DAE & $8692.76^{*}$ & $192.79^{\text {ns }}$ & - & $224.28^{\text {ns }}$ & - & - & - \\
\hline & Monocotyledons at harvest & $34509.05^{*}$ & $1479.17^{\mathrm{ns}}$ & - & $2064.73^{\mathrm{ns}}$ & - & - & - \\
\hline & Total at $26 \mathrm{DAE}$ & $7258.83^{*}$ & $131.94^{\mathrm{ns}}$ & - & $204.95^{\text {ns }}$ & - & - & - \\
\hline & Total at harvest & 415804.11* & $1701.34^{\mathrm{ns}}$ & - & $2530.99^{\mathrm{ns}}$ & - & - & - \\
\hline \multirow{4}{*}{ Soybean } & Pods per plant & $14103.61 *$ & $316.78^{*}$ & $2812.50^{*}$ & $242.80^{*}$ & $69.56^{\mathrm{ns}}$ & $2.76^{\mathrm{ns}}$ & $205.74 *$ \\
\hline & Seeds per pod & $2.17 *$ & $1.29 *$ & $1.19^{*}$ & $0.42 *$ & $0.07^{\mathrm{ns}}$ & $0.52 *$ & $0.08^{\mathrm{ns}}$ \\
\hline & 100 seed weight & $49.05^{*}$ & $24.50^{*}$ & $14.73 *$ & $3.24 *$ & $1.90^{*}$ & $1.03^{\mathrm{ns}}$ & $1.28^{\mathrm{ns}}$ \\
\hline & Crop yield & $387298.30^{*}$ & $28614.15^{*}$ & $126472.30^{*}$ & $772442.40^{*}$ & $172753.45^{\text {ns }}$ & $236332.70^{\text {ns }}$ & $66171.23^{\text {ns }}$ \\
\hline
\end{tabular}

DAE - days after emergence of soybeans, ns - não significant, * significant at $5 \%$ by the F-test. 
(redroot pigweed), Desmodium tortuosum (dixie ticktrefoil), Spermacoce latifolia (buttonweed), Chamaescy hirta (asthma weed), Tridax procumbens (coat buttons), Senna obtusifolia (sicklepod), Ageratum conyzoides (goatweed), Blainvillea latifolia (Para Cress Flower), Bidens pilosa (hairy beggarticks), Commelina benghalensis (Benghal dayflower), Sonchus oleraceus (common sowthistle), Euphorbia heterophylla (Mexican fireplant), Galinsoga ciliata (shaggy soldier), Solanum americanum (American Black Nightshade), Croton glandulosus (vente conmigo), Physalis angulata (cutleaf groundcherry), Echinochloa crusgalli (barnyardgrass), Paspalum maritimum (caostal sand paspalum).

No effects were observed for the interaction between sowing times and soybean cultivars, or for soybean cultivars as the main factor in the assessments of the weed community. There were only effects of sowing times on the dry weight of dicotyledonous weeds at harvest of soybean cultivars, on the dry weight of monocotyledonous species and on the total dry weight of the weed community at the two sampling times (Table 2 and Figure 2). Both in the assessments at $26 \mathrm{DAE}$ and at harvest of the soybean cultivars, interference problems with weeds were higher for the sowing held in December, except for the dicotyledons evaluated at soybean harvest, as shown in Figure 2. It is evident that the proper sowing time for soybeans allowed better development of cultivars, increasing greater competitive potential against weeds, although there were no differences in the competitive potential of the cultivars. However, the choice of cultivars is an important tool in weed management, mainly because of properties such as emergency speed, height, dry matter accumulation and canopy architecture (Shaw et al., 1997). This fact was reported by Pires et al. (2005), whose evaluation of the competitive potential of soybean cultivars against weeds showed that early-cycle cultivars Emgopa 316 and Coodetec 204, and medium-cycle cultivar Emgopa 315 had higher competitive ability against weeds, which were recommended for areas of high weed infestation.

There were significant interactions for crop yield (sowing time $\mathrm{x}$ cultivars), number of pods per plant (sowing time $\mathrm{x}$ cultivar $\mathrm{x}$ weed management), number of seeds per pod (cultivars $\mathrm{x}$ sowing time and sowing time $\mathrm{x}$ weed management) and 100 seed weight (cultivars $x$ sowing time and weed management $\mathrm{x}$ cultivars); as the main factor, there was a significant effect of weed management on yield of soybeans. It was observed that for all the cultivars, regardless of cycle and sowing time, crop yield was reduced by $30 \%$ on average, with no weed control (Figure 3). Similar results were found by Nepomuceno et al. (2007), who evaluated weed interference in soybean in conventional sowing system and reported a $32 \%$ drop in the yield of the crop when it coexisted with weeds throughout their cycle. Pires et al. (2005), assessing the competitive potential of soybean cultivars against weeds, observed reductions of approximately $480 \mathrm{~kg} \mathrm{ha}^{-1}$, regardless of the variety used in average levels of productivity of $2.570 \mathrm{~kg} \mathrm{ha}^{-1}$.

A further analysis of the interaction between cultivars and sowing time revealed
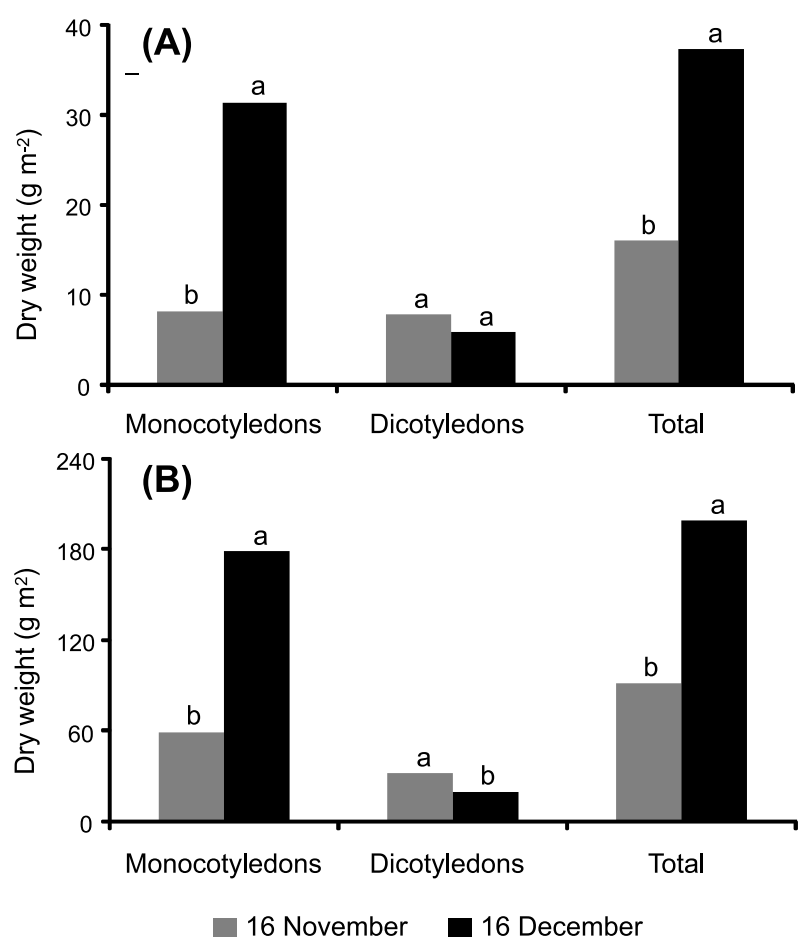

Figure 2 - Dry weight of weeds evaluated at 26 days after emergence (DAE) (A) and at harvest (B) of soybean cultivars sown at two sowing times. Data were transformed into $x$ for analysis. Means followed by the same letters are statistically similar by the Tukey's test at $5 \%$ significance. 


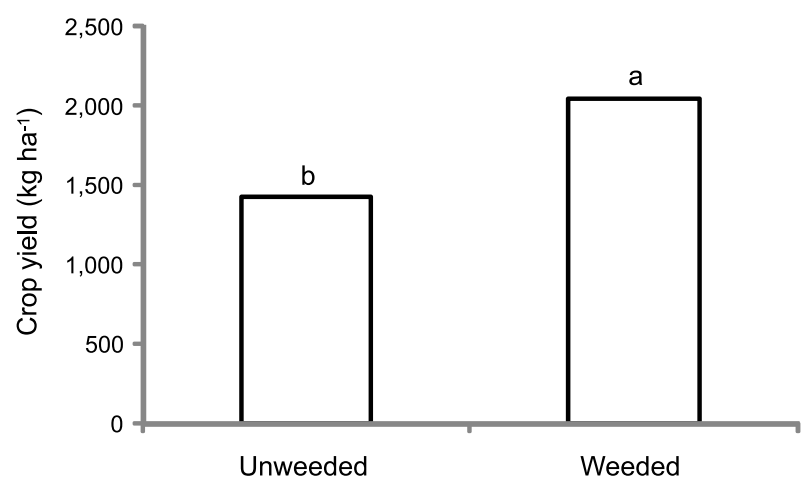

Figure 3 - Yield of soybeans in coexistence (unweeded) and in the absence of coexistence (weeded) with weeds. Means followed by the same letters are statistically similar by the Tukey's test at $5 \%$ significance.

significant effects for yield and 100 seed weight and the number of seeds per pod, where the November sowing season usually provided the best results for these variables in soybean cultivars (Table 3). For the sowing held in November, cultivars P98Y 11 and BRSGO 7560 were the most productive, and they also had the heaviest seeds, along with BRSGO Raíssa (Table 3). For the sowing held in December, BRSGO Raíssa maintained a high rate of translocation of photoassimilates to seed filling, showing greater 100 seed weight compared to other cultivars, although the cultivars Emgopa 302RR and BRSGO Indiara also showed the same efficiency when compared with the cultivars sown in November (Table 3). Among the factors analyzed, inherent to late sowing, the drought in February may have been the main determinant of the reduction of crop yield and its components: number of pods per plant, seeds per pod and crop yield. It is noteworthy, however, that other environmental factors, such as reduction of photoperiod and high temperature peaks, especially if associated with drought, contribute significantly to the reduction of the cycle and soybean yield. Several factors can affect the expression of the genetic potential of cultivars, characterized by their better growth, development and productivity, particularly photoperiod, soil fertility, temperature, plant density, sowing time (Rao \& Carvalho, 2007), weeds (Pires et al., 2005; Barros et al., 2009), among other factors. In the interaction between weeds and soybean cultivars, it was observed that when in coexistence with weeds, cultivars BRSGO Raíssa and P98Y11 were less affected by the weeds in relation to the 100 seed weight, while P98C81, BRSGO Amaralina and Emgopa RR 302 were the most sensitive (Table 4). Several studies show significant reductions in the 100 seed weight of soybeans when the crop suffers the competition from weeds (Silva et al., 2008; Pittelkow et al., 2009), especially at higher densities of infestation. In the absence of competition against weeds, cultivars BRSGO Raíssa and P98Y11, along with BRSGO 7560 and

Table 3 - Crop yield (CY), 100 seed weight (HSW) and number of seeds per pod (NSP) in soybean sown in November and December 2009

\begin{tabular}{|c|c|c|c|c|c|c|}
\hline \multirow{2}{*}{ Cultivars } & \multicolumn{2}{|c|}{ CY $\left(\mathrm{kg} \mathrm{ha}^{-1}\right)^{)^{\prime}}$} & \multicolumn{2}{|c|}{$\operatorname{HSW}(\mathrm{g})$} & \multicolumn{2}{|c|}{ NSP } \\
\hline & 16 Nov. & 16 Dec. & 16 Nov. & 16 Dec. & 16 Nov. & 16 Dec. \\
\hline BRSGO Amaralina & $2164.86 \mathrm{BCDa}$ & $821.74 \mathrm{Cb}$ & $12.47 \mathrm{CDa}$ & $11.22 \mathrm{BCb}$ & $1.99 \mathrm{Aa}$ & $1.52 \mathrm{CDb}$ \\
\hline BRSGO 7560 & $2723.44 \mathrm{ABa}$ & $1996.48 \mathrm{Ab}$ & $15.05 \mathrm{Aa}$ & $12.04 \mathrm{Bb}$ & $2.23 \mathrm{Aa}$ & $2.29 \mathrm{Aa}$ \\
\hline BRSGO Raíssa & $2112.09 \mathrm{BCDa}$ & $995.85 \mathrm{Cb}$ & $14.64 \mathrm{ABa}$ & $14.14 \mathrm{Aa}$ & $1.91 \mathrm{Aa}$ & $1.77 \mathrm{BCa}$ \\
\hline BRSGO Caiapônia & $2484.73 \mathrm{BCa}$ & $1652.86 \mathrm{ABb}$ & $12.63 \mathrm{CDa}$ & $11.24 \mathrm{BCb}$ & $2.25 \mathrm{Aa}$ & $2.09 \mathrm{ABa}$ \\
\hline Emgopa302RR & $1815.22 \mathrm{Da}$ & $1282.28 \mathrm{BCb}$ & $11.46 \mathrm{Da}$ & $11.39 \mathrm{BCa}$ & $2.19 \mathrm{Aa}$ & $2.35 \mathrm{Aa}$ \\
\hline BRSGO Indiara & $2007.42 \mathrm{CDa}$ & $760.12 \mathrm{Cb}$ & $13.31 \mathrm{BCa}$ & $12.59 \mathrm{Ba}$ & $1.86 \mathrm{Aa}$ & $1.54 \mathrm{CDb}$ \\
\hline P98C 81 & $1765.13 \mathrm{Da}$ & $719.82 \mathrm{Cb}$ & $11.17 \mathrm{Da}$ & $10.02 \mathrm{Cb}$ & $2.01 \mathrm{Aa}$ & $1.15 \mathrm{Db}$ \\
\hline P98Y11 & $3221.70 \mathrm{Aa}$ & $1264.32 \mathrm{BCb}$ & $13.97 \mathrm{ABCa}$ & $12.15 \mathrm{Bb}$ & $2.34 \mathrm{Aa}$ & $2.00 \mathrm{ABCb}$ \\
\hline $\mathrm{CV}(\%)$ plots & \multicolumn{2}{|c|}{15.54} & \multicolumn{2}{|c|}{8.68} & \multicolumn{2}{|c|}{13.51} \\
\hline CV (\%) subplots & \multicolumn{2}{|c|}{13.50} & \multicolumn{2}{|c|}{7.67} & \multicolumn{2}{|c|}{15.67} \\
\hline CV (\%) subsubplots & \multicolumn{2}{|c|}{10.68} & \multicolumn{2}{|c|}{6.79} & \multicolumn{2}{|c|}{14.88} \\
\hline
\end{tabular}

1/ Means followed by the same letters, lowercase letters in the rows and uppercase letters in the columns are statistically similar by the Tukey's test at $5 \%$ significance. 
BRSGO Indiara, stood out by the greater 100 seed weight produced (Table 4).

Table 4 - 100 seed weight in soybean cultivars grown in the presence (unweeded) and absence (weeded) of weeds

\begin{tabular}{|l|l|l|}
\hline \multirow{2}{*}{\multicolumn{1}{|c|}{ Cultivars }} & \multicolumn{2}{c|}{100 seed weight $(\mathrm{g})^{\frac{1}{}}$} \\
\cline { 2 - 3 } & Unweeded & Weeded \\
\hline BRSGO Amaralina & $10.73 \mathrm{DEb}$ & $12.96 \mathrm{BCa}$ \\
\hline BRSGO 7560 & $13.21 \mathrm{Aba}$ & $13.89 \mathrm{ABa}$ \\
\hline BRSGO Raíssa & $14.24 \mathrm{Aa}$ & $14.55 \mathrm{Aa}$ \\
\hline BRSGO Caiapônia & $11.85 \mathrm{BCDa}$ & $12.01 \mathrm{CDa}$ \\
\hline Emgopa 302 RR & $11.30 \mathrm{CDEa}$ & $11.56 \mathrm{Da}$ \\
\hline BRSGO Indiara & $12.43 \mathrm{BCb}$ & $13.47 \mathrm{ABa}$ \\
\hline P98C81 & $10.35 \mathrm{Ea}$ & $10.84 \mathrm{Da}$ \\
\hline P98Y11 & $12.94 \mathrm{Aba}$ & $13.19 \mathrm{ABCa}$ \\
\hline
\end{tabular}

${ }^{1 /}$ Means followed by the same letters, lowercase letters in the rows and uppercase letters in the columns are statistically similar by the Tukey's test at $5 \%$ significance.

When soybeans were sown in November, all cultivars did not differ in the number of seeds per pod (Table 3). However, when sown in December, the most productive cultivars as to crop yield were BRSGO 7560 and BRSGO Caiapônia. Coupled with the productive potential of these cultivars, the property long juvenile period for sensitivity to day length and stimulus to flowering may have contributed to their good performance even in late sowing. Early sowing also avoided that periods of drought coincided with flowering and seed filling. BRSGO 7560 and BRSGO Caiapônia, along with P98Y11 and Emgopa 302RR, had the highest number of seeds per pod compared to other cultivars. The number of seeds per pod of soybean cultivars also suffered interaction of sowing times and weed management; under competition against weeds in sowing held in December, the soybean cultivars produced fewer seeds per pod (Table 5). Reductions in seed yield per pod during competition between weeds and soybeans were also reported by Silva et al. (2008) and Pittelkow et al. (2009).

Sowing time significantly influenced the number of pods per plant, regardless of weed management: all the cultivars had lower pod yield in sowing held in December (Table 6). In sowing held in November, a comparison between the control environments and those with coexistence between weeds and soybean showed that the production of pods for BRSGO 7560, BRSGO Caiapônia, BRSGO Indiara, PC98C81 and P98Y11 was affected by weed interference. Several studies indicate a reduction in the number of pods of soybean plants under weed competition (Martins, 1994; Pittelkow et al. (2009), while others show that among the components of soybean yield, number of pods per plant is the most severely affected (Silva et al., 2008), even under low weed infestation. Also for this sowing time, in terms of weed control, cultivars P98C81 and BRSGO Indiara had the highest number of pods per plant compared to the others, while in coexistence with weeds, BRSGO 7560, BRSGO Raíssa, BRSGO Caiapônia, Emgopa 302RR, BRSGO Indiara and P98C82 had a higher number of pods per plant (Table 7 ).

For sowing held in December, which produced the lowest number of soybean pods, it was observed that this effect was potentiated in soybean cultivars under weed interference. Under these conditions, only the variety P98C81 showed no difference in the management of the woods; yet, for this time of sowing, irrespective of the woods, the production of this variety was very low (Table 7). In coexistence, all cultivars showed low performance and did not differ among themselves, which resulted in low crop yield.

Given the above, it is clear that weeds interfere with the growth and yield of soybean cultivars, but such interferences are minimized when the cultivars develop under better environmental conditions, conferred by the appropriate sowing time recommended for each region, which favors their maximum genetic expression.

Table 5 - Number of seeds per soybean pod sown in November and December 2009 and cultivated in the presence (unweeded) and absence (weeded) of weeds

\begin{tabular}{|l|c|c|}
\hline \multirow{2}{*}{ Sowing time } & \multicolumn{2}{|c|}{ Seeds per pod ${ }^{1 /}$} \\
\cline { 2 - 3 } & Unweeded & Weeded \\
\hline 16 November & $2.07 \mathrm{Aa}$ & $2.13 \mathrm{Aa}$ \\
\hline 16 December & $1.68 \mathrm{Bb}$ & $2.00 \mathrm{Aa}$ \\
\hline
\end{tabular}

${ }_{1 /}$ Means followed by the same letters, lowercase letters in the rows and uppercase letters in the columns are statistically similar by the Tukey's test at $5 \%$ significance. 
Table 6 - Number of pods per plant in soybean cultivars established at two sowing times (November and December) and cultivated in the presence (unweeded) and absence (weeded) of weeds

\begin{tabular}{|c|c|c|c|}
\hline \multirow{2}{*}{ Weed management } & \multirow{2}{*}{ Cultivars } & \multicolumn{2}{|c|}{ Sowing time $\mathrm{e}^{1 /}$} \\
\hline & & 16 November & 16 December \\
\hline \multirow{8}{*}{ Unweeded } & BRSGO Amaralina & $34.63 \mathrm{a}$ & $12.45 \mathrm{~b}$ \\
\hline & BRSGO 7560 & $36.25 \mathrm{a}$ & $20.73 \mathrm{~b}$ \\
\hline & BRSGO Raíssa & $38.63 \mathrm{a}$ & $12.90 \mathrm{~b}$ \\
\hline & BRSGO Caiapônia & $48.38 \mathrm{a}$ & $18.88 \mathrm{~b}$ \\
\hline & Emgopa 302 RR & $36.93 \mathrm{a}$ & $20.55 \mathrm{~b}$ \\
\hline & BRSGO Indiara & $37.13 \mathrm{a}$ & $9.48 \mathrm{~b}$ \\
\hline & P98C81 & $37.90 \mathrm{a}$ & $18.33 \mathrm{~b}$ \\
\hline & P98Y11 & $31.50 \mathrm{a}$ & $17.73 \mathrm{~b}$ \\
\hline \multirow{8}{*}{ Weeded } & BRSGO Amaralina & $35.65 \mathrm{a}$ & $29.93 \mathrm{~b}$ \\
\hline & BRSGO 7560 & $45.40 \mathrm{a}$ & $33.15 \mathrm{~b}$ \\
\hline & BRSGO Raíssa & $36.70 \mathrm{a}$ & $21.50 \mathrm{~b}$ \\
\hline & BRSGO Caiapônia & $60.23 \mathrm{a}$ & $32.80 \mathrm{~b}$ \\
\hline & Emgopa 302 RR & $39.05 \mathrm{a}$ & $26.65 \mathrm{~b}$ \\
\hline & BRSGO Indiara & $41.35 \mathrm{a}$ & $19.60 \mathrm{~b}$ \\
\hline & P98C81 & $66.53 \mathrm{a}$ & $16.10 \mathrm{~b}$ \\
\hline & P98Y11 & $49.08 \mathrm{a}$ & $28.65 \mathrm{~b}$ \\
\hline CV (\%) plots & \multicolumn{3}{|c|}{22.01} \\
\hline CV (\%) subplots & \multicolumn{3}{|c|}{26.74} \\
\hline CV (\%) subsubplots & \multicolumn{3}{|c|}{18.76} \\
\hline
\end{tabular}

${ }^{1 /}$ Means followed by the same letters in the rows are statistically similar by the Tukey's test at $5 \%$ significance.

Table 7 - Number of pods per plant in soybean cultivars established at two sowing times (November and December 2009) and cultivated in the presence (unweeded) and absence (weeded) of weeds

\begin{tabular}{|c|c|c|c|}
\hline \multirow{2}{*}{ Sowing time } & \multirow{2}{*}{ Cultivars } & \multicolumn{2}{|c|}{ Pods per plant ${ }^{1 /}$} \\
\hline & & Unweeded & Weeded \\
\hline \multirow{8}{*}{16 November } & BRSGO Amaralina & $34.63 \mathrm{Ba}$ & $35.65 \mathrm{Da}$ \\
\hline & BRSGO 7560 & $36.25 \mathrm{ABb}$ & $45.40 \mathrm{CDa}$ \\
\hline & BRS-GO Raíssa & $38.63 \mathrm{ABa}$ & $36.70 \mathrm{CDa}$ \\
\hline & BRSGO Caiapônia & $48.38 \mathrm{Ab}$ & $60.23 \mathrm{ABa}$ \\
\hline & Emgopa 302 RR & $36.93 \mathrm{ABa}$ & $39.05 \mathrm{CDa}$ \\
\hline & BRSGO Indiara & $37.13 \mathrm{ABb}$ & $41.35 \mathrm{CDa}$ \\
\hline & P98C81 & $37.90 \mathrm{ABb}$ & $66.53 \mathrm{Aa}$ \\
\hline & P98Y11 & $31.50 \mathrm{Bb}$ & $49.08 \mathrm{BCa}$ \\
\hline \multirow{8}{*}{16 December } & BRSGO Amaralina & $12.45 \mathrm{Ab}$ & $29.93 \mathrm{ABa}$ \\
\hline & BRSGO 7560 & $20.73 \mathrm{Ab}$ & $33.15 \mathrm{Aa}$ \\
\hline & BRS-GO Raíssa & $12.90 \mathrm{Ab}$ & $21.50 \mathrm{ABCa}$ \\
\hline & BRSGO Caiapônia & $18.88 \mathrm{Ab}$ & $32.80 \mathrm{Aa}$ \\
\hline & Emgopa 302 RR & $20.55 \mathrm{Ab}$ & $26.65 \mathrm{ABCa}$ \\
\hline & BRSGO Indiara & $9.48 \mathrm{Ab}$ & $19.60 \mathrm{BCa}$ \\
\hline & P98C81 & $18.33 \mathrm{Aa}$ & $16.10 \mathrm{Ca}$ \\
\hline & P98Y11 & $17.73 \mathrm{Ab}$ & $28.65 \mathrm{ABCa}$ \\
\hline
\end{tabular}

1/ Means followed by the same letters, lowercase letters in the rows and uppercase letters in the columns are statistically similar by the Tukey's test at $5 \%$ significance. 


\section{LITERATURE CITED}

BARBOSA, V. S. et al. Comportamento de cultivares de soja em diferentes épocas de semeaduras visando a produção de biocombustiveis. R. Ci. Agron., v. 42, n. 3, p. 742-749, 2011.

BARROS, H. B.; SEDIYAMA, T. Luz, umidade e temperatura. In: SEDIYAMA, T. (Ed.). Tecnologias de produção e uso da soja. Londrina: Mecenas, 2009. p. 17-27.

BARROS, H. B.; SILVA, A. A.; SEDIYAMA, T. Manejo de plantas daninhas. In: SEDIYAMA, T. (Ed.). Tecnologias de produção e uso da soja. Londrina: Mecenas, 2009. p. 101-118.

BARROS, H. B. et al. Efeito das épocas de semeadura no comportamento de cultivares de soja no sul do Estado do Tocantins. R. Ceres, v. 50, n. 291, p. 565-570, 2003

BONATO, E. R. et al. Desempenho de cultivares de soja em três épocas de semeadura no Rio Grande do Sul. Pesq. Agropec. Bras., v. 33, n. 6, p. 879-884, 1998.

COMPANHIA NACIONAL DE ABASTECIMENTO CONAB. Acompanhamento de safra: grãos, nono levantamento, junho 2012. Brasília: 2012.

EMBRAPA-SOJA. Tecnologia de produção de soja Região Central do Brasil 2011. Londrina: Embrapa Soja/ Embrapa Cerrados/Embrapa Agropecuária Oeste, 2010 (Sistemas de Produção, 14).

FEHR, W. R.; CAVINESS, C. E. Stages on soybean development. Ames: Iowa State University/Cooperative Extention Service, 1977. 11 p. (Special Report, 80).

FERRARI, R. A. et al. Biodiesel da soja - taxa de conversão em ésteres etílicos, caracterização físico-quimica e consumo em gerador de energia. Química Nova, v. 28, n. 1, p. 19-23, 2005.

GAZZIERO, D. L. P. et al. Manejo e controle de plantas daninhas em soja. In: VARGAS, L.; ROMAN, E. S. Manual de manejo e controle de plantas daninhas. Bento Gonçalves: Embrapa Uva e Vinho, 2004. p. 595-635.

LAMEGO, F. P. et al. Tolerância a interferência de plantas competidoras e habilidade de supressão por genótipos de soja - II. Repostas de variáveis de produtividade.

Planta Daninha, v. 22, n. 4, p. 491-498, 2004.

MARTINS, D. Interferência de capim-marmelada na cultura da soja. Planta Daninha, v. 12, n. 2, p. 93-99, 1994.

MOTTA, I. S. et al. Características agronômicas e componentes da produção de sementes de soja em diferentes épocas de semeadura. R. Bras. Sementes, v. 22, n. 2 , p. $153-162,2000$.
NEPOMUCENO, $M$. et al. Períodos de interferência das plantas daninhas na cultura da soja nos sistemas de semeadura direta e convencional. Planta Daninha, v. 25, n. 1, p. 43-50, 2007.

PELUZIO, J. M. et al. Comportamento de cultivares de soja no Sul do Estado do Tocantins. Biosci. J., v. 21, n. 3, p. 113-118, 2005.

PIRES, F.R. et al. Potencial competitivo de cultivares de soja em relação as plantas daninhas. Planta Daninha, v. 23, n. 4 , p. 575-581, 2005.

PITTELKOW, F. K. et al. Interferência de plantas daninhas na cultura da soja transgênica. Global Sci. Technol., v. 2, n. 3, p. $38-48,2009$.

RADOSEVICH, S. R. et al. Weed ecology. Implications for vegetation management. 2.ed. New York: John Wiley Professio, 1997. 608 p.

RAMBO, L. et al. Rendimento de grãos da soja em função do arranjo de plantas. Ci. Rural, v. 33, n. 3, p. 405-411, 2003.

REZENDE, P. M; CARVALHO, E. A. Avaliação de cultivares de soja (Glycine max (L.) Merrill) para o sul de Minas Gerais. R. Ci. Agrotecnol., v. 31, n. 6, p. 1616-1623, 2007.

SEDIYAMA, T. et al. Origem, evolução e importância econômica. In: SEDIYAMA, T. (Ed.). Tecnologias de produção e uso da soja. Londrina: Mecenas, 2009. p. 101-118

SHAW, D. R. et al. Sicklepod (Senna obtusifolia) interference with soybean (Glycine max) cultivars following herbicide treatments. Weed Technol., v. 11, n. 3, p. 510-514, 1997.

SILVA, A. F. et al. Densidades de plantas daninhas e épocas de controle sobre os componentes de produção da soja.

Planta Daninha, v. 26, n. 1, p. 65-71, 2008.

SILVEIRANETO, A. N. et al. Desempenho de linhagens de soja em diferentes locais e épocas de semeadura em Goiás. Pesq. Agropec. Trop., v. 35, n. 2, p. 103-108, 2005.

TEIXEIRA, I. R. et al. Competição entre feijoeiros e plantas daninhas em função do tipo de crescimento dos cultivares. Planta Daninha, v. 27, n. 2, p. 235-240, 2009.

URBEN FILHO, G.; SOUZA, P. I. M. Manejo da cultura da soja sob cerrado: época, densidade e profundidade de semeadura. In: ARANTES, E. N.; SOUZA, P. M. (Eds). Cultura da soja nos cerrados. Belo Horizonte: Potafos, 1993. $535 \mathrm{p}$. 